\title{
Monetary Policy and Its Price Stabilization Effects on the Prices of Building Materials
}

\author{
1 Joseph Ufere Kalu \\ 2 Zakka Ze Gyang \\ 1 Godwin Uche Aliagha \\ 1 Buang Alias \\ 1 Onuoha Iheanyichukwu Joachim \\ 1 Department of Real Estate, Faculty of Geoinformation and Real Estate, Universiti Teknologi Malaysia, Johor, Malaysia \\ ${ }^{2}$ Department of Building, Abubakar Tafawa Balewa University, Bauchi State, Nigeria
}

\section{Doi:10.5901/mjss.2015.v6n4p171}

\section{Abstract}

Inflation has an influence on the general economic activities of the market system, and this includes the building materials market. The influence of inflation on the price of building materials results in variations in the financial planning and execution of a construction project, which hampers meeting the cost targets and maintain profit margin. It is the responsibility of government to regulate the movement of inflation through the use of Monetary Policies. The monetarist economists argue that the major cause of inflation is the increase in the supply of money in circulation. The Monetary Policy being the principal tool used by the government for price stabilization in mind, this study aims to examine the relationship between the inflationary rates and prices of building materials in the face of Monetary Policy. The study covers a period of ten years and considered twenty-four (24) major construction materials. The result shows that there is a significant relationship between the movement of the Monetary Policy Rate (MPR) and the inflation rate. A regression model of $y=6894+0.314 x$, which imply that MPR controls price fluctuation in the general economy, this was not the case with the prices of building materials investigated. The regression of the prices of the building materials against the MPR showed no significant relationship; though the price fluctuated within the period. MPR did not show to have an effect on movement of building material price; hence MPR may not be an effective tool for price stabilization in the building materials market.

Keywords: Monetary Policy Rate (MPR), Inflation, Building Materials, Price

\section{Introduction}

Monetary policy is the process by which the government, central bank, or regulatory power of an economy manages (i) the provision of cash, (ii) accessibility to cash, and (iii) cost of cash. To acquire a set of goals focused towards the development and balance of the economic system (Jahan, 2014). There have been a positive results in inflation targeting according to Bernanke, Gertler, and Gilchrist (1999) and Corbo, Di Gregorio, and Levine (2001). Monetary and fiscal policies are used to regulate macroeconomic factors, with its increasing effects on the macroeconomic indices. Over the years, the impact of monetary policies on prices of building materials has generated interest especially as it concerns project budgeting and construction management. Studies have examined the effects of macroeconomic variables on construction industry in developing economies (Akintoye, Bowen, \& Hardcastle, 1998; Lopes, 1998; Lopes, Ruddock, \& Ribeiro, 2002; Wong, Chiang, \& Ng, 2008). Monetary policy and inflation are variables of importance in the economy so studying their relationships and effects of the macroeconomic variables is of interest to economists. Inflationary pressure makes it difficult for proper planning and execution of construction projects to meet cost targets and maintain a profit margin. In Nigeria, inflation has been moving upward, reaching double digits and the surplus of country's currency the Naira in circulation, scarcity of food and fuel are part of the effect (Dike, 2010). The high cost of building materials has been identified as one of the major problems militating against adequate housing supply in Nigeria (Agbola, 1998).

The cost of building projects depends largely on the prices of the inputs, such as materials, machines, and manpower. Rapidly rising (inflation) and falling (deflation) prices of inputs lead to insecurity and an increased risk that could harm the economy. Rising prices erodes the purchasing power of money, so workers demand higher wages. Companies would in turn factor the higher wages into their products which result, is a spiral with salaries and prices both push each other up while interest rates increase as well. In such circumstances, consumers and businesses are left without solid ground to base sound economic decisions. Hence, price stability is a necessary precondition for a healthy economy. 
The monetary policy involves regulating the quantity and cost of money, this undertaken by the monetary authority of a country to influence the national economy and to maintain price stability (Jahan, 2014). However, little is still known about the relationship between inflation and the price of building materials. This study aims at assessing the effectiveness of monetary policy in regulating inflationary effect on the price of building materials and examines the success of the price stabilization effort in the construction material market.

\section{Literature Review}

\subsection{Monetary Policy}

Monetary policy is the process by which the monetary power of a country manages the provision of cash, often focusing on the rate of rising prices or attention ensures price balance and general trust in the currency. Monetary plan is referred to as either being expansionary or contractionary. Where an expansionary plan increases the total provision of cash in the economy more rapidly than regular, and contractionary plan increases the cash provision more slowly than regular or even reduces it. The expansionary plan is trusted to try to combat the lack of employment in a recession by lowering attention levels in the hope that easy credit will attract businesses into growing. The contractionary plan is intended to slow rising prices to avoid the resulting disturbances and destruction of resource values (Jahan, 2014). To monitor inflation, Monetary Policy Rate can be implemented by changing the size of the monetary base. The change in monetary policy rate directly changes the total amount of money circulating in the economy. Central bank can change its monetary base by using its open market operations such as purchase or sale of bonds and disbursement or collection of hard currency payments. The exerting of regulatory control over banks by changing the proportion of total assets that banks must hold in reserve with it, discount window lending and interest rate; regulates money in circulaton and inflation.

Monetary policy is a measure designed to control the supply of money and credit conditions in an economy (Okigbo, 2008.). The purpose of monetary policy regulation is to achieve macroeconomic goals of price stability, wealth distribution, efficient resource allocation, a favorable balance of payment and industrial development. The monetary policy unit of the central bank is tasked with the responsibility for the formulation and maintaining responsible monetary policies in order to aid the attainment of the set objectives. However, the issuance of these monetary policies has not been effectual. These macroeconomic indicators reflect the general performance of the economy and determine the viability of the economy, particularly in the construction industry sector (Altman, 2006). In discussing the development of monetary policy in Nigeria, Nnanna (2001) stated that the efficacy of monetary policy has be undermined, but still records success in monetary targeting and indirect monetary control. The Keynesians claim that the monetary policy may influence the aggregate demand, by modifying the money supply, which may lead to full employment, without generating inflation. At the beginning of the ' 80 s, the Keynesian theories lose credibility to the Monetary theories which is held high by economists such as Milton Friedman, Karl Brunner and Alton Meltzer. Monetary theorists suggest that monetary regulation can stabilize economy. The neoclassic economy brings in the rational expectations theory (Silviu, 2012). Macroeconomic stability is one of the principle aims of fiscal and monetary policy (Folawewo \& Osinubi, 2006). For monetary policy to regulate economic stability, its policy should be set so that its major targets are well defined.

Inflation is a general and sustained rise in the aggregate level of prices measured by an index of the cost of various goods and services. Repetitive price increases erode the value of money and other financial assets with fixed values, thereby creating severe economic pressures. The anticipation of future developments can cause demand for goods and services to exceed the supply available at existing prices or when possible output is restricted by faltering productivity and marketplace constraints. Sustained price increases were historically directly linked to wars, poor harvests, political upheavals, or other unique events (Jones, 2007). The effect of inflation on the economy makes it essential for it to be checked. Bamisile (2004) was of the opinion that building materials account for approximately $60 \%$ of the total cost of building projects. The fluctuation in the price of building materials will have a significant effect on the total cost of a construction project and its profit margin.

Price stability emerges as one of the most important objectives of the monetary policy. The focus is on maintaining a steady mid-level, a relative stability and not an absolute one. The American economist Blinder (1998) stated that price stability is established when populaces stop debating and worrying about inflation. Castelnuovo and Surico (2003), notice that the countries that practice inflation targeting regime do not use an explanatory definition of price stability but are characterized by the announcement of the inflation target. Greenspan (2004)defines price stability as the situation in which the influence of marking price levels is low enough not to make a difference for companies and household decisions. Bernanke (2006), referring to price stability, declares that it is both a purpose in itself, as well as a means for monetary policy because it contributes to economic growth, and to macroeconomic stability. Price stability has been 
accomplished when currency can conserve its value over time, or the erosion rate for the purchasing power is reduced. Some authors have emphasized that price stability represents an important objective for monetary policy because price instability, manifested as inflation, can have long and intense consequences on a national economy. Fischer (1993) considers that, operationally speaking, price stability should represent an inflation rate between 0 and $3 \%$. The high rate of inflation of the past century required a deep reform process, during which central banks were held responsible for reaching target points of inflation.

Oladipo and Oni (2012) considered the effect of macroeconomic measures on the prices of building materials with respect to its impact on improving construction project procurement and delivery. The findings showed that critical scales affecting the prices of building materials include the inflation rate, exchange rate, interest rate and money supply. Also Olaniyan (2000) specified that inflation and its variability are parts of the significant indicators of macroeconomic instability in Nigeria with significant negative impact on investment. In another study that investigated banks' lending behavior by Somoye and Ilo (2009) associated macroeconomic variables with long-term concern for instability in the industry and the other economic sectors.

The construction sector, which undertakes infrastructural projects, contributes about half of the total stock of national fixed capital investment and generates employment opportunities in the Nigeria economy. The Nigerian construction industry is one sector that has the economic potential of contributing over $15 \%$ growth to the nation's GDP within the next nine years (2020). Oforeh (2006) argued that infrastructure is critical to human and economic development and is the catalyst for attracting investment; Nigeria has enormous potentials due to her huge deficit in infrastructure.

\subsection{Theory of Monetary Policy}

Monetary policy uses a variety of tools to economic growth, inflation, exchange rates with other currencies and unemployment. Where currency is under a monopolistic issuance, or where there is a regulated system of issuance of currency through the apex bank; the monetary authority has the ability to alter the money supply and thus influence the interest rate to achieve policy goals. It is important for decision makers to make credible policies if private agents (consumers and firms) will believe that policy makers are committed to regulating inflation for general future lower prices. If an employee expects prices to be high in the future, wage contracts will draw up to match these prices. Hence, the expectation of lower wages is reflected in wage-setting behavior between employees and employers (lower wages since prices are expected to be lower). Since wages are lower, there will be no demand pull inflation because employees will receive smaller salaries; and there will be no cost push inflation because employers will pay out less in wages. A high wage will increase a consumer's demand (demand pull inflation) and a firm's costs (cost push inflation), so inflation arises. Governments use fiscal policy to influence the level of aggregate demand in the economy, in an effort to achieve economic objectives of price stability, full employment, and economic growth.

Keynesian economics suggests that increasing government spending and decreasing tax rates are the best ways to stimulate aggregate demand, and decreasing spending and increasing taxes after the economic boom begins. Keynesians argued that this method could in times of recession or low economic activity be an essential tool for building the framework for a strong economic growth and working towards full employment. Governments can use a budget surplus to slow down the pace of strong economic growth and secondly to stabilize prices when there is inflation. Keynesian theory posits that removing spending from the economy will reduce levels of aggregate demand and contract the economy, thus stabilizing prices.

\section{Methodology}

The data for this work was collected from the review of published prices of various building materials from the Nigeria Institution of Quantity Surveyors (NIQS). The data on inflationary rates and Monetary Policy Rates were obtained from the Central Bank of Nigeria (CBN) Statistical Bulletin.

The SPSS software was used in the data analysis with simple regression and correlation analysis used as the statistical instruments for the research. The aim of the statistical investigation is to establish the nature of the relationship between MPR and prices of the selected building construction materials.

\subsection{Scopes}

The study is limited to a ten (10) year period and the price of 24 building materials studied: cement (50kg bag), mild steel 
reinforcement bars, high yield reinforcement bars, BRC wire mesh, washed gravel, unwashed gravel, granite, sharp sand, soft sand, laterite, hardcore, hollow sand Crete block $(100 \mathrm{~mm})$, hollow sand Crete block $(150 \mathrm{~mm})$, hollow sand Crete block $(225 \mathrm{~mm})$. Others include load bearing block $(150 \mathrm{~mm})$, load bearing block $(225 \mathrm{~mm})$, hardwood $(50 \times 50 \times 3600 \mathrm{~mm})$, hardwood $(50 \times 75 \times 3600 \mathrm{~mm})$, hardwood $(50 \times 100 \times 3600)$, hardwood $(50 \times 150 \times 3600)$ emulsion paint, gloss oil paint, sandtex rendering, and tex cote fireproof paint.

\subsection{Method of Analysis}

Simple linear regression and Correlation were used for analysis; regression analysis is used to assess two or more variables considered to be systematically connected by a linear relationship. Correlation is a measure of the linear dependence between variables giving a value of +1 and -1 inclusive.

\subsubsection{Simple Regression Analysis:}

The analysis comprises of the simple linear function in the form

$Y=a+b x$

Where $a$ is the intercept on the $T$ - axis when $x=0$;

$b$ is the slope.

The coefficient "an" and "b" of the simple regression linear function are determined by;

$\mathrm{b}=\frac{n\left(\sum x_{i} y_{i}\right)-\left(\sum x_{i}\right)\left(\sum y_{i}\right)}{n\left(\sum x_{i}{ }^{2}\right)-\left(\sum x_{i}\right)^{2}}$,

and $\mathrm{a}=\mathrm{Y}-\mathrm{bx}$

where: $Y$ is a dependent variable.

$x$ is an independent variable.

Decision Rule: The simple regression analysis used the coefficient of determination R2, $t_{c}$ (t- calculated), and tt (ttabulated) as a basis for the conclusion for the research.

\section{Data Presentation, Analysis and Discussion}

Table 1. Depicts the average yearly inflation rate (in \%), Monetary Policy Rate (in \%), and annual prices of building construction materials (in Naira).

\begin{tabular}{|c|c|c|c|c|c|c|c|c|c|c|c|c|c|c|c|}
\hline $\begin{array}{c}\text { S/ } \\
\text { No. }\end{array}$ & $\begin{array}{c}\text { MPR } \\
(\%)\end{array}$ & $\begin{array}{c}\text { Inflation } \\
\text { Rate } \\
(\%)\end{array}$ & $\begin{array}{c}\text { Cement } \\
\left(\begin{array}{l}50 \mathrm{~kg} \\
\text { bag) }\end{array}\right.\end{array}$ & $\begin{array}{c}\text { Mild } \\
\text { Steel } \\
\text { Bars }\end{array}$ & $\begin{array}{c}\text { High Yield } \\
\text { Steel } \\
\text { Bars }\end{array}$ & $\begin{array}{c}\text { BRC } \\
\text { wire } \\
\text { Mesh }\end{array}$ & $\begin{array}{c}\text { Washed } \\
\text { Gravel }\end{array}$ & $\begin{array}{c}\text { Unwashed } \\
\text { Gravel }\end{array}$ & Granite & $\begin{array}{c}\text { Sharp } \\
\text { Sand }\end{array}$ & Soft Sand & Laterite & $\begin{array}{c}\text { Hard- } \\
\text { core }\end{array}$ & $\begin{array}{c}\text { 100mm Hollow } \\
\text { Block }\end{array}$ & $\begin{array}{c}150 \mathrm{~mm} \text { Hollow } \\
\text { Block }\end{array}$ \\
\hline 1 & 13.5 & 8.5 & 500 & 34,000 & 32,000 & 9,000 & 6,000 & 6,500 & 6,800 & 3,000 & 3,100 & 1,500 & 3,000 & 28 & 32 \\
\hline 2 & 14.31 & 10 & 510 & 33,000 & 35,000 & 9,600 & 12,000 & 9,800 & 16,500 & 3,100 & 3,400 & 2,100 & 3,100 & 28 & 33 \\
\hline 3 & 18 & 6.6 & 510 & 33,000 & 35,000 & 9,600 & 12,000 & 9,800 & 16,500 & 3,100 & 3,400 & 2,100 & 3,100 & 28 & 33 \\
\hline 4 & 13.5 & 6.9 & 500 & 31,000 & 32,500 & 9,000 & 12,000 & 9,500 & 16,500 & 3,000 & 3,300 & 1,880 & 3,000 & 30 & 35 \\
\hline 5 & 14.31 & 18.9 & 650 & 45,000 & 31,000 & 8,000 & 6,000 & 6,500 & 16,500 & 3,000 & 3,100 & 1,500 & 3,000 & 30 & 32 \\
\hline 6 & 19 & 12.9 & 600 & 45,000 & 31,900 & 8,000 & 6,000 & 6,500 & 6,800 & 3,000 & 3,100 & 1,500 & 3,000 & 30 & 32 \\
\hline 7 & 15.75 & 14 & 600 & 45,000 & 31,000 & 8,000 & 6,000 & 6,500 & 6,800 & 3,500 & 3,000 & 1,500 & 3,000 & 30 & 32 \\
\hline 8 & 15 & 15 & 700 & 75,000 & 95,000 & 19,000 & 12,000 & 9,000 & 18,000 & 6,500 & 7,000 & 3,000 & 6,000 & 45 & 50 \\
\hline 9 & 13 & 19.9 & 1000 & 88,000 & 55,000 & 19,000 & 12,000 & 9,000 & 18,000 & 7,000 & 7,000 & 3,000 & 7,000 & 50 & 60 \\
\hline 10 & 14 & 8.5 & 1200 & 88,000 & 96,000 & 19,000 & 12,000 & 9,000 & 18,000 & 7,000 & 7,000 & 3,000 & 5,000 & 50 & 70 \\
\hline 11 & 8 & 6.4 & 1500 & 96,000 & 96,000 & 19,000 & 12,000 & 9,000 & 18,000 & 7,000 & 7,000 & 4,000 & 8,000 & 50 & 80 \\
\hline
\end{tabular}

Table 1 (contd.): Yearly Monetary Policy Rate, Inflation Rate and Prices of Building Construction Materials.

\begin{tabular}{|c|c|c|c|c|c|c|c|c|c|c|c|c|}
\hline $\begin{array}{l}\text { S/ } \\
\text { No. }\end{array}$ & $\begin{array}{c}\text { MPR } \\
(\%)\end{array}$ & $\begin{array}{l}225 \mathrm{~mm} \\
\text { Hollow } \\
\text { Block }\end{array}$ & $\begin{array}{l}150 \mathrm{~mm} \text { Load } \\
\text { Bearing Block }\end{array}$ & $\begin{array}{l}225 \mathrm{~mm} \text { Load } \\
\text { Bearing Block }\end{array}$ & $\begin{array}{c}\text { Hard-wood } \\
(50 \times 50 x \\
3600 \mathrm{~mm})\end{array}$ & $\begin{array}{c}\text { Hardwood } \\
(50 \times 75 x \\
3600 \mathrm{~mm})\end{array}$ & $\begin{array}{c}\text { Hardwood } \\
(50 \times 100 x \\
3600 \mathrm{~mm})\end{array}$ & $\begin{array}{c}\text { Hardwood } \\
(50 \times 150 x \\
3600 \mathrm{~mm})\end{array}$ & $\begin{array}{c}\text { Emulsion } \\
\text { Paint }\end{array}$ & $\begin{array}{c}\text { Gloss } \\
\text { Oil Paint }\end{array}$ & $\begin{array}{c}\text { Sandtex } \\
\text { Rendering }\end{array}$ & $\begin{array}{c}\text { Tex cote } \\
\text { Paint }\end{array}$ \\
\hline 1 & 13.5 & 39 & 50 & 50 & 80 & 120 & 160 & 250 & 450 & 888 & 3,000 & 3,000 \\
\hline 2 & 14.31 & 41 & 60 & 84 & 95 & 120 & 160 & 250 & 615 & 1,000 & 3,000 & 3,000 \\
\hline 3 & 18 & 41 & 60 & 84 & 95 & 120 & 160 & 250 & 615 & 1,000 & 3,000 & 3,000 \\
\hline 4 & 13.5 & 39 & 60 & 72 & 90 & 140 & 165 & 260 & 615 & 1,000 & 3,000 & 3,000 \\
\hline 5 & 14.31 & 45 & 50 & 50 & 80 & 140 & 180 & 270 & 450 & 1,000 & 3,500 & 3,700 \\
\hline 6 & 19 & 45 & 50 & 50 & 80 & 140 & 180 & 270 & 450 & 888 & 3,500 & 3,700 \\
\hline 7 & 15.75 & 45 & 50 & 50 & 80 & 140 & 180 & 270 & 450 & 888 & 3,500 & 3,700 \\
\hline 8 & 15 & 70 & 80 & 80 & 250 & 350 & 450 & 700 & 550 & 888 & 3,500 & 3,700 \\
\hline 99 & 13 & 80 & 80 & 90 & 250 & 350 & 450 & 700 & 550 & 1,200 & 3,500 & 3,700 \\
\hline \begin{tabular}{|l|}
10 \\
\end{tabular} & 14 & 90 & 80 & 90 & 250 & 350 & 450 & 700 & 550 & 1,200 & 3,500 & 3,700 \\
\hline \begin{tabular}{|l|}
11 \\
\end{tabular} & 8 & 95 & 80 & 90 & 250 & 350 & 450 & 700 & 500 & 1,200 & 3,500 & 3,700 \\
\hline
\end{tabular}




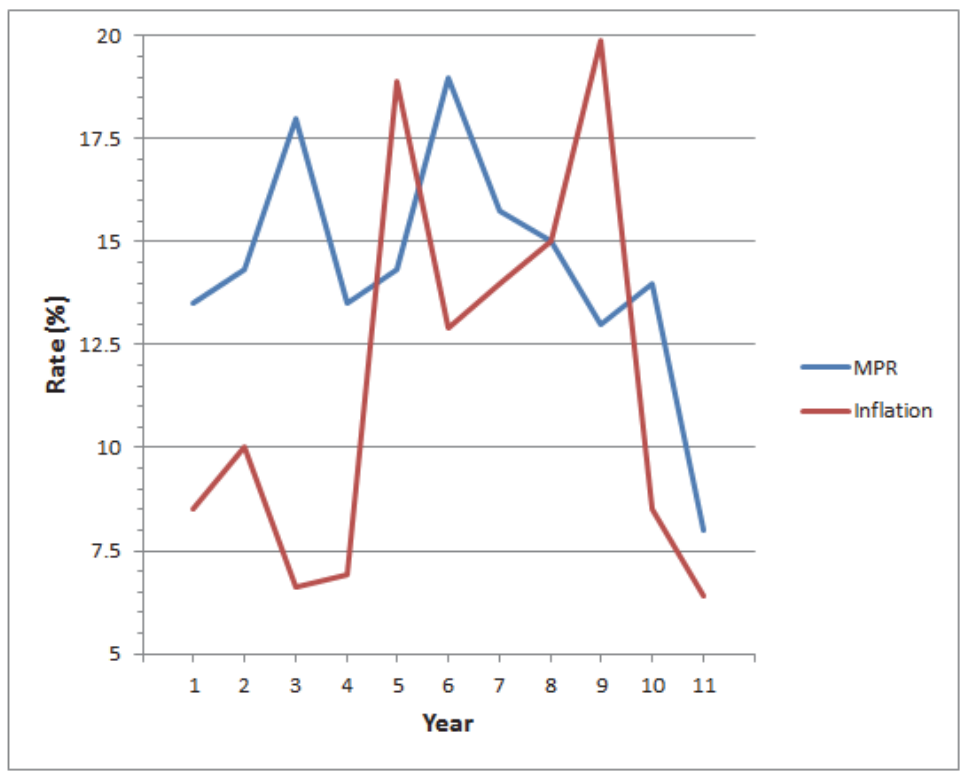

Figure 1: Trend of MPR and Inflation within the study period.

Table 2: Regression Analysis of Inflation Rate and Prices of Building Construction Materials.

\begin{tabular}{|c|c|c|c|c|c|c|c|c|c|c|}
\hline Model & X-axis & Y-axis & Regression Equation & $\mathrm{R}^{2}(\%)$ & $t_{c}$ & $\mathrm{t}_{\mathrm{t}}$ & Remark & $\begin{array}{c}\text { Correlation } \\
(\%)\end{array}$ & $\mathrm{t}_{\mathrm{c}}(0.05)$ & Remark \\
\hline 1 & Inflation & Cement & $841.902-7.890 x$ & 1 & -0.323 & 0.754 & $\begin{array}{c}\text { No Significant } \\
\text { Difference }\end{array}$ & -10.7 & 0.754 & Significant \\
\hline 2 & Inflation & Mild Steel & $42319.545+604.976 x$ & 1.3 & 0.343 & 0.739 & $\checkmark$ & 11.4 & 0.739 & $\checkmark$ \\
\hline 3 & Inflation & High Yield Steel & 55175.504-207.250x & 0 & 0.10 & 0.923 & $\checkmark$ & -33 & 0.923 & $\checkmark$ \\
\hline 4 & Inflation & BRC Mesh & $12143.21+28.841 x$ & 0 & 0.076 & 0.941 & $\checkmark$ & 2.5 & 0.941 & $\checkmark$ \\
\hline 5 & Inflation & Washed Gravel & $12666.0-249.420 x$ & 14 & -1.215 & 0.255 & $\checkmark$ & -37.5 & 0.255 & $\checkmark$ \\
\hline 6 & Inflation & Unwashed Gravel & $9867.229-138.85 x$ & 19 & -1.462 & 0.178 & $\checkmark$ & $\begin{array}{l}-43.8 \\
\end{array}$ & 0.178 & $\checkmark$ \\
\hline 7 & Inflation & Granite & $17946.76-187.853 x$ & 10.9 & -1.047 & 0.322 & $\checkmark$ & -32.9 & 0.322 & $\checkmark$ \\
\hline 8 & Inflation & Sharp Sand & $4091.11+26.607 x$ & 0 & 0.207 & 0.841 & $\checkmark$ & 6.9 & 0.841 & $\checkmark$ \\
\hline 9 & Inflation & Soft Sand & $4287.11+26.607 x$ & 0 & 0.190 & 0.853 & $\checkmark$ & 6.3 & 0.853 & $\checkmark$ \\
\hline 10 & Inflation & Laterite & $2580.859-35.107 x$ & 3.6 & -0.577 & 0.578 & $\checkmark$ & 18.9 & 0.578 & $\checkmark$ \\
\hline 11 & Inflation & Hardcore & $4763.501-17.50 x$ & 0 & -0.109 & 0.916 & $\checkmark$ & -3.6 & 0.916 & $\checkmark$ \\
\hline 12 & Inflation & 100mm Hollow Block & $35.910+0.207 x$ & 0 & 0.283 & 0.783 & $\checkmark$ & 9.4 & 0.785 & $\checkmark$ \\
\hline 13 & Inflation & 150mm Hollow Block & $51.364-0.605 x$ & 2.4 & -0.471 & 0.649 & $\checkmark$ & -15.5 & 0.649 & $\checkmark$ \\
\hline 14 & Inflation & 225mm Hollow Block & $57.062+0.018 x$ & 0 & 0.011 & 0.991 & $\checkmark$ & 0 & 0.991 & $\checkmark$ \\
\hline 15 & Inflation & 150mm Load Bearing Block & $66.042-0.211 x$ & 0 & -0.212 & 0.837 & $\checkmark$ & -7 & 0.837 & $\checkmark$ \\
\hline 16 & Inflation & 225mm Load Bearing Block & $35.180-1.91 x$ & 7 & -0.825 & 0.431 & $\checkmark$ & -26.5 & 0.431 & $\checkmark$ \\
\hline 17 & Inflation & Hardwood (50×50×3600mm) & $133.191+1.074 x$ & 1.6 & 0.177 & 0.863 & $\checkmark$ & -5.9 & 0.863 & $\checkmark$ \\
\hline 18 & Inflation & Hardwood (50x75x3600mm) & $176.258+30.038 x$ & 1.6 & 0.378 & 0.714 & $\checkmark$ & 12.5 & 0.714 & $\checkmark$ \\
\hline 19 & Inflation & Hardwood (50x100×3600mm) & $225.961+39.76 x$ & 1.6 & 0.386 & 0.708 & $\checkmark$ & 12.8 & 0.708 & $\checkmark$ \\
\hline 20 & Inflation & Hardwood (50x150×3600mm) & $357.115+5.507 x$ & 1.3 & 0.341 & 0.741 & $\checkmark$ & 11.3 & 0.743 & $\checkmark$ \\
\hline 21 & Inflation & Emulsion Paint & $617.289-7.525 x$ & 24 & -1.688 & 0.126 & $\checkmark$ & -49.0 & 0.126 & $\checkmark$ \\
\hline 22 & Inflation & Gloss Oil Paint & $1061.754-2.606 x$ & 0 & -0.253 & 0.806 & $\checkmark$ & $\begin{array}{l}-8.4 \\
\end{array}$ & 0.806 & $\checkmark$ \\
\hline 23 & Inflation & Sandtex Rendering & $2942.061+32.941 x$ & 34.4 & 2.220 & 0.054 & $\begin{array}{l}\text { Significant } \\
\text { Difference }\end{array}$ & 59.5 & 0.054 & $\checkmark$ \\
\hline 24 & Inflation & Tex cote Paint & $2918.655+46.117 x$ & 35.4 & 2.220 & 0.054 & $\begin{array}{l}\text { Significant } \\
\text { Difference }\end{array}$ & 59.5 & -0.054 & $\checkmark$ \\
\hline
\end{tabular}

Table 2 shows a regression of inflation and the prices of the twenty-four selected building materials. It indicates that in two models was the slope of the regression equation significantly different from zero while no significant difference in slope was noticed in the other twenty-two materials.

The correlation analysis between the inflation rate and prices showed that sixteen prices exhibited significant negative relationship at $95 \%$ level of confidence, and eight showed a significant positive relationship. When $t_{c}>t_{a}$, there is a significant difference between the beta value and zero; $\mathrm{t}_{c}<\mathrm{t}_{\mathrm{a}}$ there is no significant difference. 
Table 3: Regression Analysis of MPR and Prices of Building Construction Materials.

\begin{tabular}{|c|c|c|c|c|c|c|c|c|c|c|}
\hline Model & X-axis & Y-axis & Regression Equation & $\mathrm{R}^{2}(\%)$ & $t_{c}$ & $\mathrm{t}_{\mathrm{t}}$ & Remark & Correlation (\%) & $\mathrm{t}_{c}(0.05)$ & Remark \\
\hline 1 & MPR & Inflation & $6894+0.314 x$ & 3.9 & 0.601 & 0.553 & $\begin{array}{l}\text { No Significant } \\
\text { Difference }\end{array}$ & - & 0.018 & Not Significant \\
\hline 2 & MPR & Cement & $1931.030-81905 x$ & 48.3 & -2.900 & 0.018 & Not Significant & -69.5 & 0.018 & Not Significant \\
\hline 3 & MPR & Mild Steel & $123622.739-4820.042 x$ & 32 & -2.060 & 0.070 & Not Significant & -56.6 & 0.070 & Significant \\
\hline 4 & MPR & High Yield Steel & 137229.820-5863.661x & 34.4 & -2.170 & 0.558 & Not Significant & -58.6 & 0.058 & Significant \\
\hline 5 & MPR & BRC Mesh & $26626.760-983105 x$ & 28.9 & -1.912 & 0.088 & Not Significant & -53.7 & 0.088 & Significant \\
\hline 6 & MPR & Washed Gravel & $15118.262-368.131 x$ & 12 & -1.107 & 0.297 & Not Significant & -34.6 & 0.297 & Significant \\
\hline 7 & MPR & Unwashed Gravel & $10070.143-124.213 x$ & 6 & -0.757 & 0.464 & Not Significant & -24.6 & 0.468 & Significant \\
\hline 8 & MPR & Granite & $24109.555-735.651 x$ & 15.2 & -1.272 & 0.235 & Not Significant & -39.0 & 0.232 & Significant \\
\hline 9 & MPR & Sharp Sand & $9812.780-374.064 x$ & 29.9 & -1.961 & 0.081 & Not Significant & -54.7 & 0.081 & Significant \\
\hline 10 & MPR & Soft Sand & 9694.951-354.514x & 27.8 & -1.862 & 0.095 & Not Significant & -52.7 & 0.095 & Significant \\
\hline 11 & MPR & Laterite & 5125.491-197.641x & 44.1 & -2.666 & 0.026 & Not Significant & -66.4 & 0.026 & Not Significant \\
\hline 12 & MPR & Hardcore & $11210.110-461.648 x$ & 35.9 & -2.244 & 0.052 & Not Significant & -59.9 & 0.052 & Significant \\
\hline 13 & MPR & 100mm Hollow Block & 64.711-1.975x & 31.5 & -2.033 & 0.073 & Not Significant & -56.1 & 0.073 & Significant \\
\hline 14 & MPR & 150mm Hollow Block & $106.583-4.315 x$ & 47.7 & -2.867 & 0.019 & Not Significant & -69.1 & 0.019 & Not Significant \\
\hline 15 & MPR & 225mm Hollow Block & $123.889-4.627 x$ & 36.0 & -2.249 & 0.051 & Not Significant & -60.0 & 0.051 & Significant \\
\hline 16 & MPR & 150mm Load Bearing Block & 99.442-2.487x & 27.0 & -1.825 & 0.101 & Not Significant & -52 & 0.101 & Significant \\
\hline 17 & MPR & 225mm Load Bearing Block & $108.939-2.515 x$ & 14.6 & -1.240 & 0.246 & Not Significant & -38.2 & 0.0246 & Not Significant \\
\hline 18 & MPR & Hardwood (50x50×3600mm) & $366.941-15.384 x$ & 27.8 & -1.861 & 0.096 & Not Significant & -52.7 & 0.093 & Significant \\
\hline 19 & MPR & Hardwood (50x75x3600mm) & $503.422-20.317 x$ & 27.3 & -1.841 & 0.099 & Not Significant & -52.3 & 0.099 & Significant \\
\hline 20 & MPR & Hardwood (50x100x3600mm) & $642.401-25.771 x$ & 27.7 & -1.813 & 0.103 & Not Significant & -51.7 & 0.103 & Significant \\
\hline 21 & MPR & Hardwood (50x150x3600mm) & $1007.611-40.814 x$ & 27.4 & -1.841 & 0.099 & Not Significant & -52.3 & 0.099 & Significant \\
\hline 22 & MPR & Emulsion Paint & $589.456-4.035 x$ & 2.7 & -0.500 & 0.629 & Not Significant & -16.4 & 0.629 & Significant \\
\hline 23 & MPR & Gloss Oil Paint & $1400.656-25.606 x$ & 26.7 & -1.811 & 0.104 & Not Significant & -5.7 & 0.104 & Significant \\
\hline 24 & MPR & Sandtex Rendering & $3471.087-10.620 x$ & 1.4 & -0.362 & 0.726 & Not Significant & -12.0 & 0.726 & Significant \\
\hline 25 & MPR & Tex cote Paint & $3659.522-14.869 x$ & 1.4 & -0.362 & 0.726 & Not Significant & -12.0 & 0.726 & Significant \\
\hline
\end{tabular}

Table 3 above shows the regression analysis between MPR and inflation rate. It shows that the model is adequate hence there is a significant difference between the slope and zero, which means that there is a relationship between MPR and inflation rate. Model 2 to 25 shows the regression between MPR and the prices of the selected materials; which shows no significant difference between the slope of the regression equation and zero. Hence, the models are inadequate.

\section{Conclusion}

In investigating the nature of the relationship between inflation rate and the prices of building materials and the effectiveness of MPR in price stabilization in the building material market. All but two of the prices of the building materials showed no significant relationship, which means that the rate of fluctuation in prices of building materials is at variance with the MPR. The study of MPR and cost of construction materials showed that there was no significant relationship between MPR and the prices of the materials. Therefore the regulatory control of MPR may not be effective on the building material market; since it did not significantly affect the prices of the materials over the study period. The MPR does not show any significant relationship with building material prices though it does with inflation. Hence, it may not be an effective economic tool for price stabilization in the building material sub-sector. There is a need to study the underlining reasons for the differences between the rate of increase in the prices of building materials and the economy's inflation rate. There is also need for the use of construction industry sectoral inflation rate for further studies on the effect of MPR on the prices of building materials. An effective and efficient regulatory policy for the building industry and the building market, in particular, should further studied.

\section{References}

Agbola, T. (1998). The Housing of Nigerians: A review of policy development and implementation in the housing sector: Development Policy Centre.

Akintoye, A., Bowen, P., \& Hardcastle, C. (1998). Macro-economic leading indicators of construction contract prices. Construction Management \& Economics, 16(2), 159-175.

Altman, M. (2006). Identifying employment-creating sectors in South Africa: the role of services industries. Development Southern Africa, 23(5), 627-647.

Bamisile, A. (2004). Building production management. Lagos: Foresight Press Ltd.

Bernanke. (2006). Reflections on the yield curve and monetary policy. Remarks before.

Bernanke, Gertler, M., \& Gilchrist, S. (1999). The financial accelerator in a quantitative business cycle framework. Handbook of macroeconomics, 1, 1341-1393. 
Blinder, A. S. (1998). Central bank independence in theory and practice: Cambridge: MIT Press.

Castelnuovo, E., \& Surico, P. (2003). What does Monetary Policy Reveal about a Central Bank's Preferences? Economic Notes, 32(3), 335-359.

Corbo, J. C., Di Gregorio, A., \& Levine, M. (2001). The ascidian as a model organism in developmental and evolutionary biology. Cell, 106(5), 535-538.

Dike, V. E. (2010). Governance and Challenges Facing the Nigerian Economy: Is Jonathan the Answer? Available at SSRN 1646202.

Fischer, S. (1993). The role of macroeconomic factors in growth. Journal of monetary economics, 32(3), 485-512.

Folawewo, A. O., \& Osinubi, T. S. (2006). Monetary policy and macroeconomic instability in Nigeria: A rational expectation approach. Journal of social sciences, 12(2), 93-100.

Greenspan, A. (2004). Risk and uncertainty in monetary policy. American Economic Review, 33-40.

Jahan, S. (2014). Inflation Targeting: Holding the Line Finance \& Development: International Monetary Funds,.

Jones, S. G. (2007). The rise of European security cooperation: Cambridge University Press.

Lopes, J. (1998). The construction industry and macroeconomy in Sub-Saharan Africa post 1970. Construction Management \& Economics, 16(6), 637-649.

Lopes, J., Ruddock, L., \& Ribeiro, F. L. (2002). Investment in construction and economic growth in developing countries. Building Research \& Information, 30(3), 152-159.

Nnanna, O. (2001). Monetary policy framework in Africa: the Nigerian experience: Working Paper Series.

Oforeh, E. (2006). The Nigerian Institute Of Quantity Surveyors As An Agent Of Economic Development. Paper presented at the 22nd Biennial Conference and General meeting of the Nigerian Institute of Quantity Surveyors, 22nd-25th Nov.

Okigbo, P. (2008.). Nigeria's financial system: . Structure and growth.

Oladipo, F., \& Oni, O. (2012). Review of Selected Macroeconomic Factors Impacting Building Material Prices in Developing Countries-A Case Of Nigeria. Ethiopian Journal of Environmental Studies and Management, 5(2), 131-137.

Olaniyan, O. (2000). The effects of economic instability on aggregate investment in Nigeria. The Nigerian Journal of Economic and Social Studies, 42(1), 23-36.

Silviu, C. (2012). Gândirea economică românească în perioada postcomunistă. Revista OEconomica(02).

Somoye, R. O. C., \& Ilo, B. M. (2009). The impact of macroeconomic instability on the banking sector lending behavior in Nigeria. Journal of Money, Investment and Banking, 7(10), 88-100.

Wong, J. M., Chiang, Y., \& Ng, T. S. (2008). Construction and economic development: the case of Hong Kong. Construction Management and Economics, 26(8), 815-826. 